\title{
腰椎黄色靭帯内血腫の一例
}

$$
\begin{aligned}
& \text { 保 利 俊 雄* 齊 藤太 } \text { 一 }^{*} \text { 入 江 努* 田 中 哲 也* } \\
& \text { 末 永 英 慈 }
\end{aligned}
$$

\section{Hematoma of the Lumbar Ligamentum Flavum : A Case Report}

Toshio Hori ${ }^{*}$, Taichi Saito*, Tsutomu Irie*, Tetsuya Tanaka*, Eiji Suenaga*, Atsushi Matsumoto*, and Yoshinao Oda**

【症例】 61 歳, 男性. 約 4 年前に L5/S1 左外側型ヘルニアに対して PLIF を施行された。術後, 左下 肢痛は消失するも左母趾の知覚異常が残存した。術後 3 年 6 か月経過後, 左下腿外側, 足背の痛みとシビ レが出現し，いったんは改善するも 4 か月経過したころから同症状が再燃し歩行困難となった。理学所見 上，左股関節外転筋と左前脛骨筋に MMT4 の筋力低下を認めた. MRI にて L4 椎体レベルの奉柱管内左 側に T1 強調像でやや高信号を呈する腫瘤影を認めた。術中所見にて同腫瘤は L4-5 左黄色勒带内から頭 側へと連続性に進展する血腫であり，これらを全て摘出した。術後，左下肢痛は消失し筋力も回復した． 【まとめ】黄色靭帯内血腫は比較的まれな疾患であるが，MRIにおける経時的な輝度变化を捉えること により術前診断が可能であると考えらえた。

We report a case of hematoma of the lumbar ligamentum flavum. A 61-year-old man presented with pain and numbness of the lateral aspect of the left leg. Although his symptoms improved once by conservative treatment, they recurred four months after his first visit and he could hardly walk due to muscle weakness of the left foot. MRI findings demonstrated an extradural mass at the left side of the L4 level which showed high signal intensity in T1WI. In surgical operation, the mass was revealed to be a hematoma that continuously progressed from the left L4-5 ligamentum flavum to the cranial side. After complete removal of this mass, his symptoms and signs disappeared remarkably.

Hematoma of the ligamentum flavum is a comparatively rare disorder, it maybe possible to diagnose it preoperatively by its characteristic intensity in MRI, especially in T1WI.

Key words : hematoma (血腫), ligamentum flavum (黄色勒带), lumbar spine（腰椎）

\section{は じめ に}

腰椎黄色鞀帯内血腫はまれな疾患ではあるが, MRI の導入とともに腰痛や下肢痛の原因疾患の一つ として報告が散見されるようになってきた。 今回われ われは, 腰椎黄色䩲帯内血腫の 1 例を経験したので文 献的考察を加え報告する.

\section{症例}

61 歳, 男性.

主訴）左下腿外側，足背の痛みとシビレ.

現病歴） 4 年前, L5/S1 左外側型ヘルニアに対して,
L5/S1 後方進入椎体間固定術を施行された。術後, 左下肢痛は消失したが, 左母趾の知覚異常が残存した. 術後 3 年 6 か月経過したころから 左下腿外側, 足背 に痛みとシビレを認め当科を受診した。保存的加療を 行い，いったん症状は改善したが，4か月経過した時 点で同症状が再燃し歩行困難となったため再診となっ た.

既往歴，生活歴）特記すべきことなし，抗凝固剂の内 服むなかった。

再診時身体所見）左股関節外転筋と左前脛骨筋に MMT4 の筋力低下を認めた。新たな知覚異常はなく， 深部腱反射は正常で病的反射は認められなかった。膀

\footnotetext{
* 福岡市民病院整形外科 Department of Orthopaedic Surgery, Fukuoka City Hospital, Fukuoka, Japan

** 九州大学形態機能病理 Department of Anatomic Pathology, Kyushu University, Fukuoka, Japan
} 


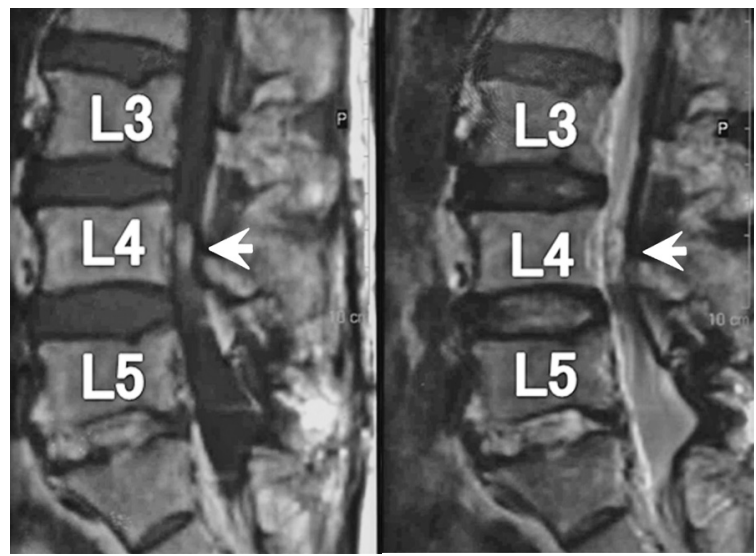

図 1 術後 3 年 6 か月（再来初診時） MRI（左：T1 強調像, 右：T2 強調像)

L4 椎体後面に, T1 強調像, T2 強調像ともに高信号の占拠性病变を認める.
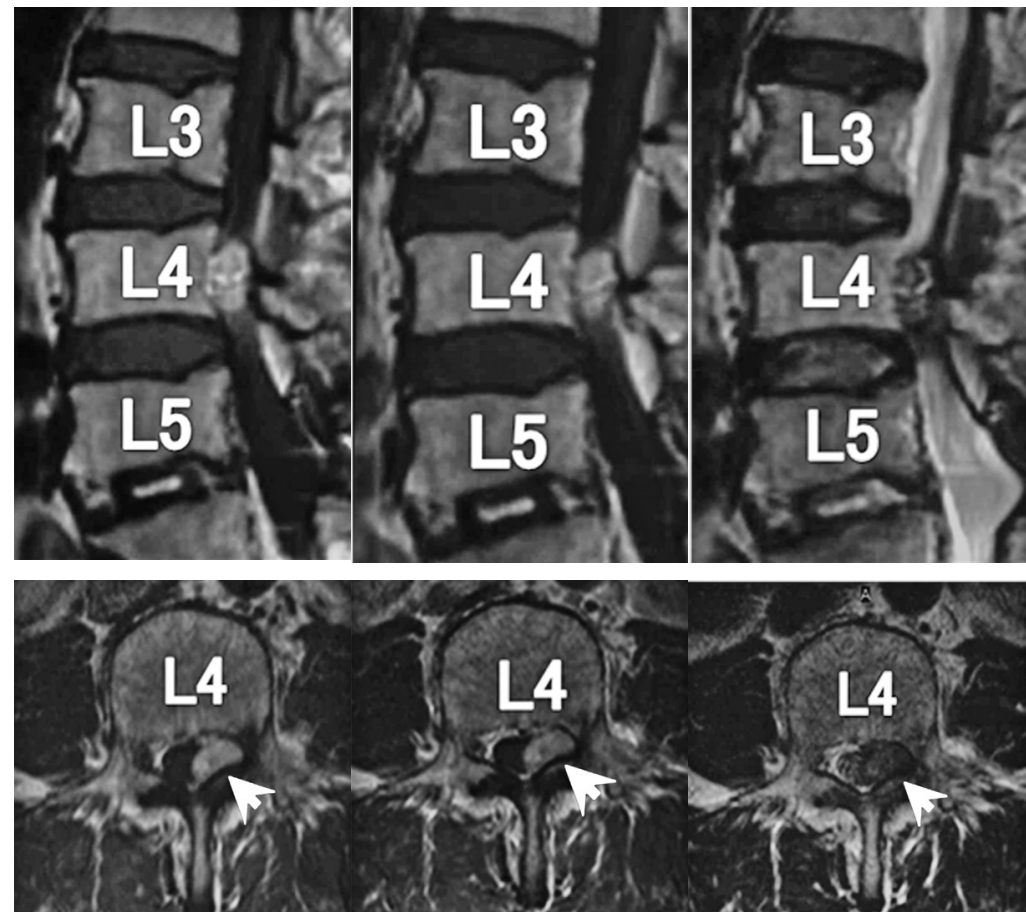

図 2 発症後 4 ヶ月 MRI（上段：矢状断像，下段：水平断像.上下段之屯に左： $\mathrm{T} 1$ 強調像, 中央：ガドリニウム造影 $\mathrm{T} 1$ 強調像, 右： $\mathrm{T} 2$ 強調像. )

$\mathrm{T} 1$ 強調像で高信号， ガドリニゥムで増強効果のない $\mathrm{T} 2$ 強調像では低信号 を呈す占拠性病変を認める。病変は初診時（図 1) よりも増大している.

胱直腸障害屯認められなかった。

血液生化学所見）出血凝固系も含め全て正常であっ た.

画像所見）単純X線像において L5/S1 間の骨癒合は
良好であり，Instrumentationの弛みなどの異常屯 認められなかった。上位腰椎に軽度の変性所見を認め た.

術後 3 年 6 か月（再来初診時）の MRI にて L4 椎 
体後面に，T1 强調像，T2 強調像ともに高信号の占拠 性病変を認妨た（図 1)。症状再燃時の MRI 矢状断 では $\mathrm{T} 1$ 強調像で高信号，ガドリニウムで増強効果の ない T2 強調像で低信号を呈す占拠性病变を認めた。

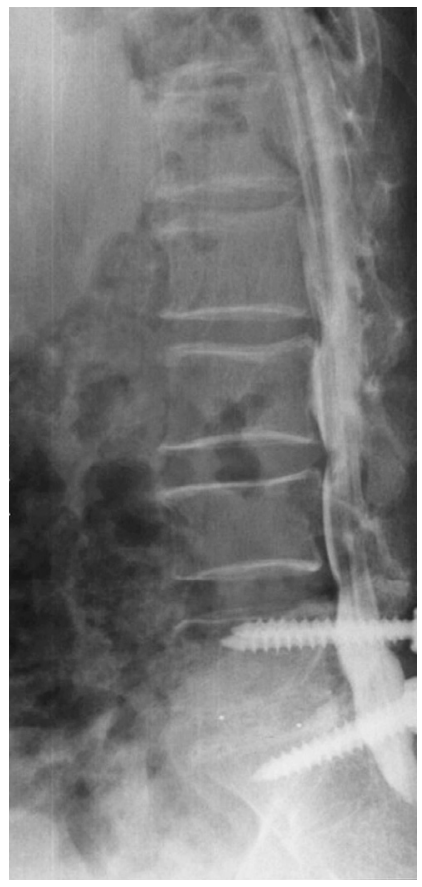

図 3 脊髄造影 (側面像)

L4 椎体レベルにおい て左側から硬膜管が強 く圧迫され, 左 L4, L5 神経根の描出が不 良である。
横断像では L4 椎体レベルで脊柱管左側に同様の占拠 性病変を認めた（図 2 )。占拠性病変の増大があり, 4 か月の間の輝度变化より血腫と診断した.

脊䯣造影では L4 椎体レベルに扔いて左側から硬膜 管が強く圧迫され，左 L4，L5 神経根の描出が不良で あった (図 3 )。脊髄造影後 CT でも同様に硬膜管が 強く圧迫されていた。

再診後経過）下肢筋力低下を伴っており，保存的治療 によっても症状の改善が得られなかったため, 手術を 施行した。術中所見では L4-5 左黄色勒帯内から頭 側（L4 椎弓根レベルまで）へ進展する血腫が観察さ れ, これらを全て摘出した。肉眼所見にて黄色勒帯内 に血腫の存在を認めた。周囲は通常の硬膜外静脈叢の みであり異常な血管奇形などは認められなかった。

術後, すみやかに左下肢痛は消失し術前に認められ た下肢筋力も回復した。病理組織学的検查では, 摘出 した黄色勒帯内に弱拡大で境界明瞭な凝固した血液を み之め, 強拡大では炎症細胞之線維芽細胞の侵潤を伴 う肉芽組織の介在が認められた（図 4 )。以上の所見 より腰椎黄色靯帯内血腫之診断した。

考察

黄色勒帯内には元来血管は存在しないが，その变性 過程において血管新生が起こることが確認されてい $3^{117)}$. 黄色勒帯内血腫は比較的稀な疾患であり, そ の発生機序に関して確定的な見解はないが, 血管奇形, 外傷, くしゃみなどによる腹圧上昇に伴う硬膜外静脈

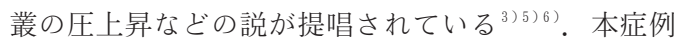
に関しては術中所見㧍よび病理組織検査より血管奇形

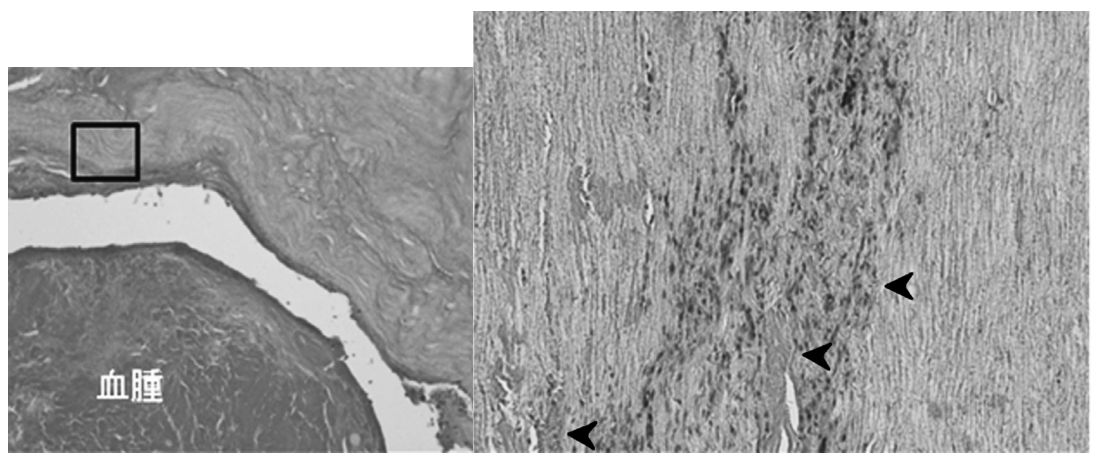

図 4 摘出標本の病理組織学的所見

摘出した黄色勒帯内には弱拡大で境界明瞭な凝固した血液を認め（左）, 強 拡大では炎症細胞と線維芽細胞の浸潤を伴う肉芽組織の介在を認める (右). 
は認められなかった。また患者は長期にわたり肉体労 働をしており, 繰り返される变性黄色勒帯への微小外 傷によって勒帯線維が部分的に断裂し, 靶帯内の微小 血管が損傷され，同部から徐々に血腫が増大していっ たむのと考えられた。

MRI における血腫の信号強度は，発症からの時間 とその組成により経時的に变化することが知られてい $ろ^{4}$ ），一般に，急性期から亜急性期前半にかけては， $\mathrm{T} 1$ 強調像で高信号, T2 強調像で低信号を呈すること が多い．亜急性期後半からは T2 強調像において高信 号を呈する部分が増加してくる。慢性期にはへモジデ リンの沈着により， T1，T2 強調像ともに低信号を呈 するようになる。一般的に $\mathrm{T} 1$ 強調像にて高信号を呈 する病態は脂肪原性の病变以外には黒色腫など極めて 稀であり, この時点で血腫は有力な鑑別診断の一因と なりうる。また，経時的な信号变化を捉える時間的な 余裕があれば，その輝度变化により，血腫の可能性は さらに高くなる.ここに矢状断像, 水平断像, 冠状断 像での撮影を組み合わせることにより病変の局在や広 がりを確認することができれば，黄色勒帯内血腫とい う診断は術前においても可能であると考えられる。本 症例では, 初診時が $\mathrm{T} 1$ 強調像, T2 強調像ともに高 信号で，症状再燃時が $\mathrm{T} 1$ 強調像で高信号， T2 強調 像で低信号であった。以上より，初診時が覀急性期， 症状再燃時が新たな血腫が生じ症状が増悪した急性期 であったと考えられた。

治療は通常の腰椎疾患に準ずるが，疼痛が高度であ
り，下肢の神経症状，特に運動麻痺を伴う場合には早 期の手術的治療が適応となる。過去の報告においても 手術により良好な結果が得られたとするあのが多い2).

\section{ま と め}

今回，比較的まれな腰部黄色靶带内血腫の 1 例を経 験した。黄色靭帯内血腫は, 黄色勒帯の变性過程で 生じた新生血管に微小外傷が加わることにより生じる あのと考えられた。 また，MRIの特徴的な輝度と経 時的な信号变化を捉えることにより術前の診断む可能 であると思われた。

\section{参 考 文 献}

1) Hirakawa, K., et al.: A post-traumatic ligamentum flavum progressive hematoma. Spine, 25(9) : 1182-1184, 2000.

2）北浜義博ら：腰椎黄色勒帯内に血腫を形成し下肢痛を きたした 2 症例一画像所見と発生機序一。 Spinal Surgery, 20(3) : 193-199, 2006.

3）北浜義博, 花北順哉：【黄色靭帯に生じる各種病変】 腰椎黄色鞀帯内血腫. 春椎脊䯣, 20(2)：143-150, 2007.

4）国松 聡，青木茂樹，大友 邦：春䯣出血性疾患，硬 膜外血腫，䯣内出血．脊椎脊䯣，14(6)：492-495，2001.

5) Mizuno, J., et al. : Ligamentum flavum hematoma in the lumbar spine. Neurol. Med. Chir. (Tokyo), 45 : 212215, 2005

6) 田 偉ら：腰仙部の黄色勒帯血腫の 1 例. 臨整外, 30 (5) : 665-668, 1995 .

7）和田大志ら：比較的まれな腰椎黄色勒帯内血腫の 1 例. 整・災外，53(4)：413-416，2010. 